\title{
Impact of Economic, Social and Environmental Variables on Competitiveness of Automotive Industry: Evidence from Panel Data
}

\author{
Abdul Hannan ${ }^{1}$, Faheem Haider ${ }^{1}$, Nisar Ahmad ${ }^{2}$, Tahira Ishaq ${ }^{3}$ \\ ${ }^{1}$ Atlas Honda Limited, Sheikhupura, Pakistan \\ ${ }^{2}$ Hailey College of Commerce, University of the Punjab, Lahore, Pakistan \\ ${ }^{3}$ Pakistan Institute of Development Economics, Islamabad, Pakistan \\ Email address: \\ abdulhannan.j@gmail.com (A. Hannan), Faheem.haider1973@gmail.com (F. Haider), nisar@hcc.edu.pk (N. Ahmad), \\ tahira.ishaq@pide.org.pk (T. Ishaq)
}

\section{To cite this article:}

Abdul Hannan, Faheem Haider, Nisar Ahmad, Tahira Ishaq. Impact of Economic, Social and Environmental Variables on Competitiveness of Automotive Industry: Evidence from Panel Data. International Journal of Economic Behavior and Organization.

Vol. 3, No. 1, 2015, pp. 10-17. doi: 10.11648/j.ijebo.20150301.12

\begin{abstract}
The study is aimed to examine the impact of economic, social and environmental factors on the competitiveness of automotive industry. Competitiveness of industry is measured by the Revealed Comparative Advantage (RCA) Index. Fixed effect model is estimated by using the data of 14 Asian countries for the period ranging from 1991 to 2012 . Results show that competitiveness of automotive industry is positively related to economic performance, human capital development, urbanization and tariff rate while negatively affected by lending rate and carbon emission both in developed and developing nations of Asia. Findings of the study suggest that external factors should be given due consideration particularly lending rate, human capital development and tariff to improve the competitiveness of automotive industry. Automotive policies in developing countries should improve their human capital and encourage foreign investors with adequate protection to local industry.
\end{abstract}

Keywords: Competitiveness, Automotive Industry, Economic Growth, Education

\section{Introduction}

Automotive sector is considered as one of major industry in any country and plays significant role in its growth. This industry is considered as the "industry of Industries" due to its backward and forward linkages. Competitiveness of this industry has recently gained exceptional importance in this globalized era and depends upon internal and external factors Changing competitive environment has compelled the manufacturing industries including automotive, to redesign their strategies. Sever competition in automotive industry is observed as firms are constantly in endeavor to gain a competitive advantage in all their operations and strategies (Czuchry et al., 2009).

Increasing importance of competiveness of automotive industry for the managers and policy makers motivated the researchers to investigate its dynamics and driving forces. Among previous studies on automotive industry, only a few studies including Winston (1987), Smith and Florida (1994),
Porter and Vander Linde (1995), later Jaffe and Palmer, (1997), Hunya (2000), Gallagher (2003) and Triebswetter \& Wackerbauer (2008) investigated the effect of external factors on sales growth and competitiveness. This study provides deep insight about competitive of automotive sector in some Asian countries by computing revealed comparative index (RCA) of each country.

Some external factors such as economic performance, lending rate, human capital development and urbanization and tariff may affect the competitiveness of automotive industry but not given due consideration by previous studies. The major factor of judging competitiveness is the ability of a nation to raise living standards (Martin, 2003). Human capital plays a vital role on any industry of a country as it enhances the competitiveness of firms (Kumar \& Chadee, 2002). Similarly, innovation and adaptation of more sophisticated technology is very important factor for growth 
of automotive industry (Fagerberg \& Verspagen, 2002).

Automotive policies in some Asian countries focus on the development of human capital, adaptation of new technology and auto cluster programs to make the local industry more competitive. Therefore, this study is focused to investigate the impact of economic (economic performance, lending rate and tariff rate), social (education and urbanization), and environmental variables (carbon emissions) on the competitiveness of automotive industry particularly in the context of Asian countries. Rest of the paper is organized as follows: after introduction of the study, review of previous studies is given in section 2, methodology and data used to investigate the effect of economic, social and environmental factors on competitiveness of automotive industry are described in section 3, data analysis results are discussed in section 4 and section 5 concludes the study.

\section{Literature Review}

Winston (1987) found that competitiveness of automobile industry in U.S. can be attained by the access of foreign producers in the market and sustaining sales growth by not imposing import limitations. He argued that government can play a role in increasing competitiveness by maintaining a suitable exchange rate, and by introducing useful employment regulation assistance programs. Smith and Florida (1994) made econometric analysis of the Japaneseaffiliated manufacturing industries in automotive related sectors. Results of this study showed that increasing trend of urbanization, larger population, educated human resource and better transportation facilities caused increase in demand and competition in automobile industry.

Porter and Vanderlnde (1995) found that adoption of emission control technology generate long term benefits while resisting to innovation in automotive sector resulted in loss of competition. Jaffe and Palmer (1997) examined positive impact of environmental regulations on the local firms. Environmental regulations stimulate competition and innovation among domestic players as compared to the foreign competitors. Hunya (2000) found that the access to foreign markets increases international competitiveness and ability to attract FDIs. Gallagher (2003) examined the role of foreign players (OEM's Ford, G.M \& Diaimler Chrysler) in the development of automotive industry in China. He found that joint ventures of these FDIs with local manufactures of automotive firms make the Chinese automotive industry more competitive as compared with Japan, U.S and Europe. Technologies like emission controls and fuel efficiency add more to competiveness.

Chen, Abeles and Burke (2004) analyzed the response of automotive industry against emission standards of light duty vehicle tailpipe emissions. They considered the period when the government policies for vehicles were tightened to adopt expensive new emission control equipment. The application of emission standard technologies seemed to have minor effect on the average sale of cars. Fai and Morgan (2007) examined the relationships among competition, innovation and change in regulation in business environment at international level. These factors have strong impact on automobile industry and can lead to give a direction for the future polices regarding this sector. Buckley, Clegg, Zheng, Siler and Giorgioni (2007) investigated the impact of foreign direct investment (FDI) on productivity level of the automotive industry of China. The results showed that there is direct relationship of FDI with the productivity that suggests the government should create conducive environment for FDI to improve productivity of automotive industry in China. Triebswetter and Wackerbauer (2008) showed that the regulatory pressure to adopt integrated environmental product innovation technology results in competitiveness among firms. This is because the innovation is undertaken by companies voluntarily and environmental legislation encourages innovation and leads to the increase in production by reducing pollution.

Muhammad, Husin and Razak (2010) analyzed the causal relationship between macroeconomic variables and sales of car in five countries over fourteen year. They found that gross domestic product has positive and significant effect on sales growth of cars while unemployment, inflation and loan rate have negative relationship with sales growth and competition. Attanasio, Koujianou and kyriazidou (2010) studied Thailand automotive industry and found that the main success story behind Thailand automotive industry is the expansion of their production network both at regional and global level. Domestic industry alignment with global market, economies of scale, and protection of local industry through tariff were found to be the reasons for expansion of automotive industry in Thailand.

Mirza and Shahrukh (2011) highlighted the technological characteristic of Pakistan automotive industry. According to them, the major challenges faced by the industry include: increase in demand of fuel efficient vehicles, rapid changes in models, familiarity with cutting costs tools and working on the user comfort of customers without compromising on quality. Literature review shows that no specific study so far has been conducted to investigate the effect of economic, social, and environmental variables on the competitiveness of automotive industry. Therefore, this study is designed to investigate the effect of economic (economic performance, lending rate and tariff rate), social (education and urbanization), and environmental variables (carbon emissions) on the competitiveness of automotive industry particularly in the context of Asian countries.

\section{Data and Methodology}

In order to investigate the impact of economic, social and environmental variables on competitiveness of automotive industry of Asian countries, following functional form is used.

Competitiveness of Automotive $=\mathrm{f}$ (GDP per capita, Lending rates, Human capital, Urbanization, Tariff, Carbon emission)

Study is carried over the sample of fourteen Asian countries with time frame ranging from 1991 to 2012. These 
fourteen Asian countries include Bangladesh, India, China, Indonesia, Iran, Japan, Korea, Malaysia, Pakistan, Philippine, Singapore, Thailand, Sri Lanka and Vietnam.

Like Bekmez, (2006), the study used modified version of revealed comparative advantage (RCA) index developed by Balassa, (1965) to measure competitiveness of automotive industry.

$$
\text { RCA index }=\ln \left(\frac{X_{i} / X_{t}}{M_{i} / M_{t}}\right)
$$

Where,

$\mathrm{Xi}$ : Export of country $\mathrm{i}$ in automotive industry

$\mathrm{Xt}$ : Total exports made by country $\mathrm{i}$

Mi: Imports of country $i$ in automotive industry

Mt: Total imports made by country $i$

If $\mathrm{RCA}>0$, it refers that export of automotive industry is greater than that import. Also, the bigger is the RCA index level greater is the competition power.

Independent variables used in the study include economic performance, lending rate, human capital development, urbanization, average tariff rate applied to manufactured products and carbon emission.

Economic Performance: The study used GDP per capita to measure the economic performance of the country. This variable would be positively related to competitiveness of automotive industry through demand and supply channels (Hunya, 2000). Higher GDP per capita shows growth in economy and increase in productivity thus increasing demand for products. Data of this variable is obtained from WDI data base.

Lending rate: It is very important economic factor that may influence the competitiveness of industry. High lending rate discourages the investors and negatively affects their ability to make investment. Consumer loan is very sensitive to interest rate which means that lesser the interest rate more will be the demand of vehicles through financing (Attanasio et al.,2008). So, negative sign is expected between lending rate and competiveness of automotive industry.WDI is used to obtain data of lending rate.

Human capital development: It means expertise, knowledge, and know-how obsessed by an individual or population, analyzed in terms of their economic value to a country. It is a social factor and measured in terms of gross enrollment as percentage of total population. Industry needs high skilled human capital to produce more competitive product in the market (Kumaret al., 2002). This study used the secondary school enrollment as proxy for human capital which is taken from WDI.

Urbanization: Total urban population is also a social factor which indicates the level of industrialization in a country. Higher the urbanization, higher will be demand for the motor vehicles (Smith et al., 1994). Thus positive relationship is expected between urbanization and competitiveness of automotive industry. Urban population defined as inhabitants living in urban or metropolitan areas. For data on urbanization is retrieved from WDI data base.

Tariff Rate: It is measured by the average tariff rate applied to manufacturing sector. A tariff is applied tax on imports or exports, calculated for traded goods. Trade theories suggest that openness has positive impact on the competitiveness of an industry (Lee, 1993). Therefore, positive relation is expected between tariff rate and competiveness of automotive industry.

Carbon Emission: Comparative advantage of an industry is also defined by the relative size of carbon footprint of a company. Carbon emission control regulations change the competitive landscape of the many industries in global market. Those vehicles which satisfy the international environment standards are more competitive in the global market (Jaffe et al., 1997). This study includes Carbon Emissions variable in the model to see the role of carbon regulation on the competiveness of automotive industry. For data on carbon emission, World Bank WDI data base is used.

\section{Econometric Model}

Panel estimation models are preferred to test the relationship of competitiveness of automotive industry with economic performance, lending rate, human capital development, urbanization, tariff rate and carbon emission. Detailed specification of estimation models is follows.

$$
y_{i t}=x_{i t} \beta+c_{i}+u_{i t}
$$

$$
\text { RCAindex }_{i t}=c_{i}+\beta_{1} Y_{i t}+\beta_{2} L R_{i t}+\beta_{3} H_{i t}+\beta_{4} U b_{i t}+\beta_{5} C E_{i t}+\beta_{6} T_{i t}+u_{i t}
$$

Where,

$\mathrm{Y}_{\mathrm{it}}=$ GDP per capita.

$\mathrm{LR}_{\mathrm{it}}=$ Lendingrates.

$\mathrm{H}_{\mathrm{it}}=$ Human capital.

$\mathrm{Ub}_{\mathrm{it}}=$ Urbanization.

$\mathrm{CE}_{\mathrm{it}}=$ Carbon Emissions.

$\mathrm{T}_{\mathrm{it}}=$ Average Applied Tariff rates for manufacturing products.

$\mathrm{t}=1991,1992,2012$

$\mathrm{i}=1,2,3,14$

$\beta_{1}, \beta_{2}, \beta_{3}, \beta_{4}, \beta_{5}, \beta_{6}$ are the parameters and $c_{i}$ is unobserved effect which also called the individual effect. $u_{i t}$ is random error that changes both across time and country. If we treat $c_{i}$ as fixed then fixed effect estimation model is used and if $c_{i}$ behaves like random variable then random effect estimation model is preferred. If the model does not contain any individual effect then Ordinary Least Square parameters are efficient (Green et al., 2003).

\subsection{Fixed Effect Estimation}

Fixed effect can be estimated by using Least Square Dummy Variable Model (LSDV), or within Effect Model or 
between Effect Model.

$$
\text { RCAindex }_{i t}=c_{2} D_{2 i}+c_{3} D_{3 i} \ldots+c_{n} D_{n i}+\beta_{1} Y_{i t}+\beta_{2} L R_{i t}+\beta_{3} H_{i t}+\beta_{4} U b_{i t}+\beta_{5} C E_{i t}+\beta_{6} T_{i t}+u_{i t}
$$

Where $D_{1 i}$ is dummy variable that takes the value 1 if $i=1$ and 0 otherwise. $D_{2 i}=1$ for country 2 i.e. $\mathrm{i}=2$ and so on. These dummies will capture all the individual effect. In order to avoid the problem of dummy variable trap we have removed the intercept. This approach is relatively easy but it creates problems when there are many groups in the panel. Only coefficient of regressors are consistent when $\mathrm{T}$ is fixed and $\mathrm{nT} \rightarrow \infty$. Coefficients of dummy variables are not consistent because number of parameters increases when $\mathrm{nT}$ increases and this problem is called incidental parameter problem (Baltagi et al., 2008). Within group effect model does not require dummy variables. It is within transformation as it subtracts each value of cross-sectional object from timemean of the variable. This transformation will remove incidental parameter problem. Run OLS on the following model to compute the parameters.

$$
\begin{aligned}
& \text { RCAindex }_{i t}-\overline{\text { RCAlndex }_{l !}}=\beta_{1}\left(Y_{i t}-\overline{Y_{l !}}\right)+\beta_{2}\left(L R_{i t}-\overline{L R_{l !}}\right)+\beta_{3}\left(H_{i t}-\overline{H_{l !}}\right)+\beta_{4}\left(U b_{i t}-\overline{U b_{l !}}\right)+\beta_{5}\left(C E_{i t}-\overline{C E_{l !}}\right)+ \\
& \beta_{6}\left(T_{i t}-\overline{T_{l ゅ}}\right)+\left(u_{i t}-\overline{u_{l !}}\right)
\end{aligned}
$$

$\overline{\text { RCAnndex }_{1}}$ is dependent variable mean of group i.

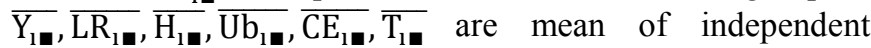
variable of group i. The within effect model has some disadvantages. This model does not report dummy coefficient and this model has large degree of freedom for error which results into small MSE and smaller standard errors for the parameters estimates.

In between group effect model, we use group means of the dependent and independent variable. it reduces the number of observation up to $\mathrm{n}$. Run OLS on the following model.

$$
\left.\overline{\text { RCAlndex }_{1}}=\mathrm{c}+\beta_{1}\left(\overline{\mathrm{Y}_{1}}\right)+\beta_{2} \overline{\left(\mathrm{LR}_{1}\right)}+\beta_{3} \overline{\left(\mathrm{H}_{1}\right.}\right)+\beta_{4}\left(\overline{\mathrm{Ub}_{1}}\right)+\beta_{5}\left(\overline{\mathrm{CE}_{1}}\right)+\beta_{6}\left(\overline{\mathrm{T}_{1}}\right)+\left(\overline{\mathrm{u}_{1}}\right)
$$

Fixed effect transformation removes the individual effect. First differencing method can also be used to remove the individual effect. This method is alternative of fixed effect transformation. But the difference lies between two estimates when time period is greater than 2 . If there are only two time periods then two estimators are same (Wooldridge et al., 2002)

If the individual effects are correlated with other regressor than the random effect model gives biased estimators. So we will prefer fixed effect model. Hausman test is used under the null hypothesis that individual effect is uncorrelated with other regressors .

\subsection{Results and Their Explanation}

To examine the competitiveness of automotive industry in fourteen Asian countries over the period from 1999 to 2012, revealed comparative advantages (RCA) index calculated by WTO is used. The comparison shows that the out of fourteen countries only five countries are competitive in terms of export of automotive products. These countries are China,
India, Thailand, Japan \& Philippines. RCA index of these five countries shows positive trend. (See Appendix table 4.1)

While it is a fact that not all markets are identical and each has its unique strengths and weaknesses. It is also a fact that essentially all successful industries have followed a pattern of sorts. Be it Thailand, China or India success has come as the industry graduated through few essential steps. Results show that average value of RCA index is negative for automotive industry which means that automotive industry is less competitive in most of the sampled Asian countries. (See Appendix table 4.1)

Further, standard deviation, minimum and maximum value of RCA index shows significant variation in competitiveness of automotive industry across 14 Asian countries during time period ranging from 1999 to 2012. Similarly, average value, standard deviation, minimum value and maximum value of independent variables show large variation in their value across country and time. (See Table 4.2)

\subsection{Descriptive Statistics of Dependent and Independent Variables}

Table 4.2. Descriptive Statistics.

\begin{tabular}{lllll}
\hline Variable Dependent/ Independent & Mean & Std. Dev. & Min & Max \\
\hline RCA & -1.17 & 2.22 & -7.02 & 4.86 \\
GDP per Capita & $7,073.48$ & $11,575.50$ & 142.97 & 51,709 \\
Lending Rate & 10.66 & 5.32 & 1.41 & 32.18 \\
Education & 68.89 & 20.83 & 23.92 & 104.47 \\
Urbanization & $1,814,030$ & 907,015 & $2,928,252$ & 699,808 \\
CO2 Emission & $606,474.90$ & $1,186,167$ & 101,000 & $1,650,000$ \\
Tariff & 76.07 & 47.02 & 10.00 & 156.00 \\
\hline
\end{tabular}


Table 4.3. Correlation Matrix.

\begin{tabular}{|c|c|c|c|c|c|c|c|}
\hline Variable Dependevt/ Independent & RCA & GDP per Capita & Lending Rate & Education & Urbanization & CO2 Emission & Tariff \\
\hline RCA & 1.0000 & & & & & & \\
\hline GDP per Capita & 0.6684 & 1.0000 & & & & & \\
\hline Lending Rate & -0.7145 & -0.4958 & 1.0000 & & & & \\
\hline Education & 0.6773 & 0.4314 & -0.5685 & 1.0000 & & & \\
\hline Urbanization & 0.6931 & 0.5383 & -0.4673 & 0.4258 & 1.0000 & & \\
\hline $\mathrm{CO} 2$ Emission & -0.5200 & 0.0455 & -0.3708 & 0.0656 & -0.0122 & 1.0000 & \\
\hline Tariff & 0.4696 & -0.0032 & -0.2678 & -0.1071 & 0.1208 & 0.2411 & 1.0000 \\
\hline
\end{tabular}

Correlation Analysis: The above table depicts that dependent variable (RCA) is highly correlated with the independent variables (GDP per Capita, Lending rate, Education, Urbanization, Co2 Emission and Tariff). Weak correlation is observed among the independent variables which mean less chances of muticollinearity among independent variable if they are used as a set in regression analysis.

\subsection{Estimation Results and Their Explanation}

\subsubsection{Hausman Test}

$H_{0}$ : Individual effect is uncorrelated with other regressor. $H_{1}$ : Individual effect is correlated with other regressor. Chi2 $(3)=(b-B)\left[\left(v_{-} b-v \_B\right)^{\wedge}(-1)\right](b-B)=7.43$ Prob $>$ Chi2 $=0.0493$

Table 4.4. Fixed Effect Model - Complete Sample.

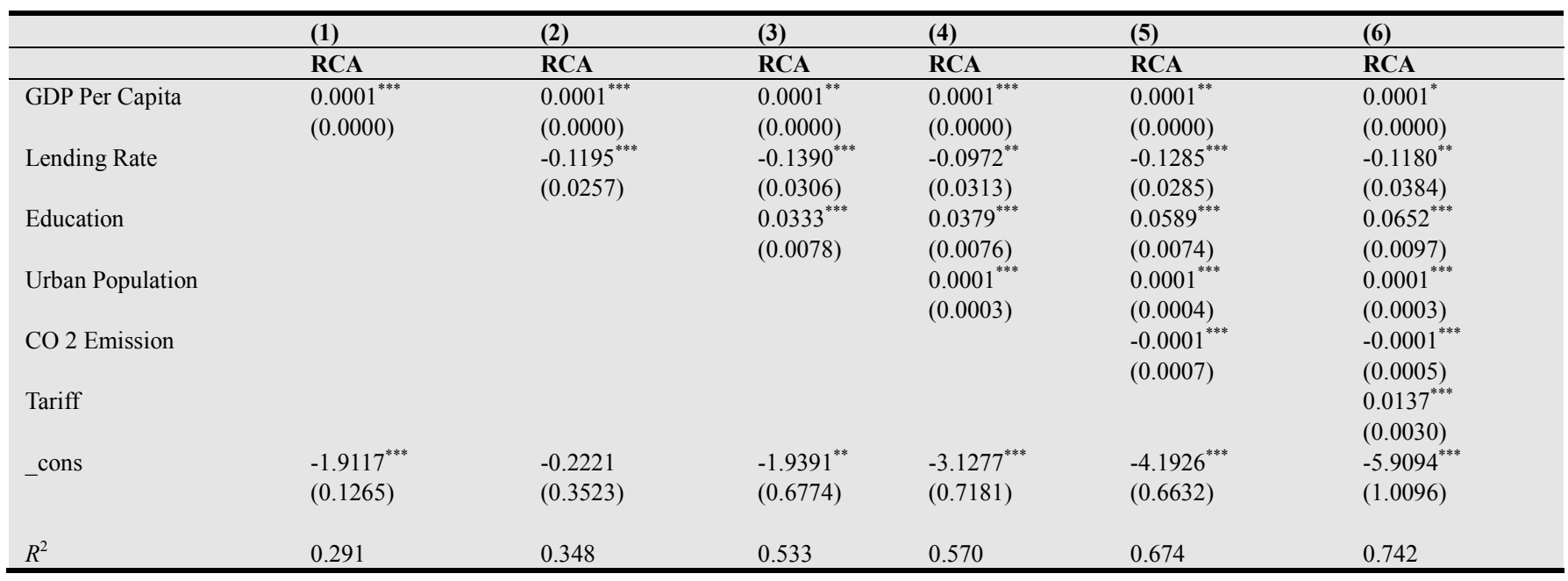

Standard errors in parentheses

${ }^{*} p<0.05,{ }^{* *} p<0.01,{ }^{* * *} p<0.001$

Table 4.4 shows the estimation results of Fixed Effect model. Results indicate that with increase in number of regressor in model, value of R-squared increases from $29 \%$ to $74 \%$. So our explanatory variables explain the $70 \%$ variation in the dependent variable. GDP per capita (measure of economic performance) is positively related to RCA index and high value of $p$ indicates that this relationship is highly significant. It means economic performance is very important for the competitiveness of automotive sector. So, economic development and growth of country do effect the growth and competition of motor vehicles through demand and supply side. High economic performance increases the living standard of people which creates more demand for vehicles.

Coefficient of lending rate indicates negative relationship with RCA index of automotive industry and shows that high lending rate may discourage the investors. In most of the developing countries, investors need large amount of funds to finance their projects especially in the auto part industry. Coefficient of human capital is positive with high value of $p$. It shows that when human capital increases by 1 unit then
RCA index increases by 0.0652. Countries with skilled human capital are more efficient in research and development activity. This result is consistent with study of (Smithet al., 1994).

Positive coefficient of urbanization indicates positive relationship between urbanization and RCA index. This result implies that as urbanization increases, more people migrate to urban areas for the job, education and medical aid which influence the demand for motor vehicles in a country (Riley, 2002). Higher demand gives the opportunity to manufacturers to acquire the economies of scale which enhances the competitiveness of industry.

Next variable is $\mathrm{CO} 2$ emissions and this variable is used as proxy for environmental emission. $\mathrm{CO} 2$ emissions and RCA index are negatively related to each other. Automotive sector is more competitive in those countries where the level of $\mathrm{CO} 2$ emission reduction is low. Suppose, the vehicles in India are more competitive than Pakistan as it achieved the Bhart IV or EURO-IV standards for its automotive sector. This relationship is consistent with the findings of Jaffe et al., 
(1997) that environmental regulations stimulate competition and innovation among firms.

Tariff variable is positively correlated to RCA index and its coefficient shows that if tariff rate increases by one unit then RCA index increases by 0.0137 units. This results shows that countries developed their automotive industries by charging higher import tariff of final products. For example, India is charging $100 \%$ duty on CBU import of automotive vehicles and achieved high economies of scale. Although it argued by the some authors that low tariff enhances the competition in industries but our results differ with these theories because this study has taken average MFN tariff rates of manufacturing sector which is applied to all non-FTA countries. Countries give access to their local markets through Free Trade Agreements.

\subsubsection{Reduced Sample Results}

Table 4.5. Fixed Effect Model - Reduced Sample results.

\begin{tabular}{|c|c|c|c|c|c|c|}
\hline & (1) & $(2)$ & (3) & (4) & (5) & (6) \\
\hline & RCA & RCA & RCA & RCA & RCA & RCA \\
\hline \multirow[t]{2}{*}{ GDP Per Capita } & $0.0001^{* * *}$ & $0.0001^{* * *}$ & $0.0001^{* *}$ & $0.0001^{*}$ & $0.0001^{*}$ & 0.0001 \\
\hline & $(0.0000)$ & $(0.0000)$ & $(0.0000)$ & $(0.0000)$ & $(0.0000)$ & $(0.0000)$ \\
\hline \multirow[t]{2}{*}{ Lending Rate } & & $-0.0905^{* *}$ & $-0.1034^{* *}$ & $-0.1730^{* * *}$ & $-0.1916^{* * *}$ & $-0.1870^{* * *}$ \\
\hline & & $(0.0316)$ & $(0.0353)$ & $(0.0358)$ & $(0.0436)$ & $(0.0436)$ \\
\hline Education & & & $0.0282^{* * *}$ & $0.0408^{* * *}$ & $0.0399^{* * *}$ & $0.0445^{* * *}$ \\
\hline \multirow[t]{2}{*}{ Tariff } & & & & $0.0398^{* * *}$ & $0.0385^{* * *}$ & $0.0343^{* *}$ \\
\hline & & & & $(0.0103)$ & $(0.0104)$ & $(0.0110)$ \\
\hline \multirow[t]{2}{*}{$\mathrm{CO} 2$ Emission } & & & & & $-0.0002^{*}$ & $-0.0001^{*}$ \\
\hline & & & & & $(0.0004)$ & $(0.0003)$ \\
\hline \multirow[t]{2}{*}{ Urban Population } & & & & & & 0.0001 \\
\hline & & & & & & $(0.000)$ \\
\hline \multirow[t]{2}{*}{ _cons } & $-0.4769^{* * *}$ & 0.5052 & -1.2266 & $-2.3485^{*}$ & -1.9685 & $-2.4247^{*}$ \\
\hline & $(0.1283)$ & $(0.3648)$ & $(0.6942)$ & $(0.8897)$ & $(1.0534)$ & $(1.1126)$ \\
\hline$R^{2}$ & 0.507 & 0.536 & 0.606 & 0.747 & 0.750 & 0.757 \\
\hline
\end{tabular}

Standard errors in parentheses

${ }^{*} p<0.05,{ }^{* *} p<0.01,{ }^{* * *} p<0.001$

Table 4.5 includes only developing countries in sample. Data of developed / developing countries is taken from World Bank. According to the definition developing countries are those whose Gross National Income (GNI) is US\$ 11,905. In a sample fourteen countries considered by this study, only two countries fall under the scope of above definition given by World Bank and these countries are Japan and South Korea. After excluding the above two countries from sample of 14 Asian countries, our results remain same as it is in case of full sample. $R^{2}$ is improved from $74 \%$ to $76 \%$ which means that $76 \%$ of the changes in dependent variable is explained by independent variables. In both samples the impact of education is very important for competitiveness of automotive industry as improved education will enhance the skill gap that ultimately leads towards the continuous improvement/ innovation

\section{Conclusion}

The main objective the study was to examine the impact of economic, social, demographic, tariff and carbon emission variables on competitiveness of automotive industry. To accomplish this objective, panel estimation technique was applied on data of fourteen Asian countries with time frame ranging from 1999 to 2012. Empirical results of this study showed that Income, education, urbanization and tariff rates are positively related to competitiveness of automotive industry. High economic performance increases the demand for the automotive products and it also increase the purchasing power of customer. Results indicate that high skilled workers increase competitiveness of automotive sector as skilled workers enhance the opportunity of innovation and efficiency in production process. Study also found that lending rate and carbon emission are negatively related to competitiveness of automotive sector. In developing countries, low lending rate encourages the entrepreneurs to invest in auto parts sectors which increase the number of players in auto part sector. This widens the base of automotive industry which provides strong base to compete in global market. Environment emission standards plays important role as the result of this study show that countries with low emission standards are more competitive in global automotive market.

Findings of this study suggest that in order to be globally competitive in automotive industry, countries needs to focus on their human capital and should provide credit to the investor's on easy credit terms. Further developing countries should improve their infrastructure and emission standards in order to remain competitive at both domestic and international market. Based on our empirical results, it is also suggested that local industries should be protected at its initial stage and make them competitive through long term consistent polices. 


\section{Appendix}

Table 4.1. Revealed Comparative Advantage Index (RCA)

Revealed Comparative Advantage Index (RCA) - Comparison

\begin{tabular}{llllllllllllllllllllll}
1991 & 1992 & 1993 & 1994 & 1995 & 1996 & 1997 & 1998 & 1999 & 2000 & 2001 & 2002 & 2003 & 2004 & 2005 & 2006 & 2007 & 2008 & 2009 & 2010 & 2011 & 2012 \\
\hline
\end{tabular} Bangladesh (4.90) (3.65) (3.12) (4.54) (4.13) (3.55) (3.98) (3.64) - $\quad$ (6.50) (7.00) (5.56) (5.56) (3.47) (2.93) (3.40) (3.80) (3.31) (5.23) (4.81) (4.34) (4.23) $\begin{array}{llllllllllllllll}\text { China } & - & (2.60)(2.76)(2.29)(1.32)(1.21)(0.71)(0.68)(0.73)(0.77)(0.87)(0.73)(1.22)(0.78)(0.16)(0.05) & 0.20 & 0.22 & 2.04 & (0.52) & (0.53)(0.42)\end{array}$

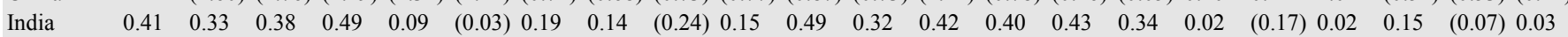
Indonesia $\quad(3.72)(2.87)(2.77)(3.25)(3.08)(2.70)(2.47)(1.14)(0.51)(1.22)(1.01)(0.44)(0.51)(0.78)(0.71)(0.20) \quad 0.05 \quad(0.75)(0.45)(0.62)(0.79)(0.82)$

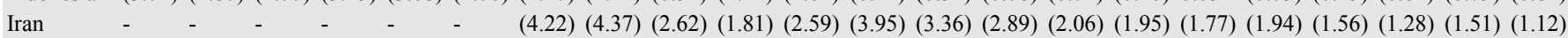
$\begin{array}{lllllllllllllllllllllll}\text { Japan } & 2.68 & 2.88 & 2.91 & 2.63 & 4.49 & 3.59 & 2.27 & 2.62 & 4.86 & 0.11 & 2.31 & 2.45 & 2.43 & 2.42 & 2.38 & 2.41 & 2.47 & 2.40 & 2.39 & 2.46 & 2.14 & 1.99\end{array}$

Korea,

$\begin{array}{lllllllllllllllllllllll}\text { Republic } & 0.68 & 1.04 & 1.41 & 1.13 & 1.34 & (0.84) & (0.51) & 2.87 & 2.42 & 2.22 & 2.23 & 1.99 & 2.11 & 2.36 & 2.31 & 2.16 & 2.04 & 1.88 & 2.05 & 2.01 & 2.02 & 2.05\end{array}$ of

Malaysia $\quad(2.41)(1.73)(1.70)(2.51)(0.05)(2.33)(2.21)(0.49)(1.13)(1.60)(1.79)(1.66)(1.46)(1.44)(1.34)(1.05)(0.92)(1.00)(1.18)(1.28)(1.23)(0.84)$ Pakistan $\quad(4.40)(5.03)(5.74)(5.10)(5.63)(5.61)(4.31)(4.05)(3.72)(4.10)(3.34)(3.77)(3.61)(3.68)(4.53)(3.70)(4.12)(3.39)(3.76)(3.68)(3.99)(4.37)$ Philippines (3.12) (2.85) (2.69) (2.40) (2.46) (2.36) (1.79) (0.52) (0.48) (0.44) $(0.46)(0.39)(0.18) 0.21 \quad 0.22 \quad 0.17 \quad 0.06 \quad 0.03 \quad(0.28)(0.47)(0.37)(0.88)$ Singapore $(1.30)(1.33)(1.33)(1.21)(1.35)(0.90)(0.86)(0.66)(0.87)(1.25)(1.15)(0.88)(0.41)(0.39)(0.31)(0.30)(0.21)(0.33)(0.12)(0.01)(0.08)(0.05)$

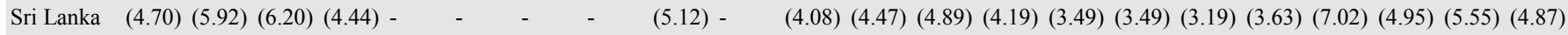

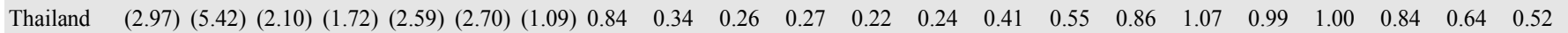

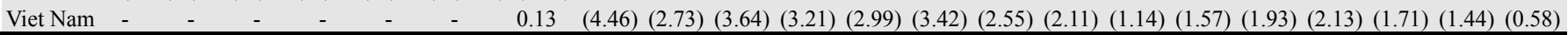

Source: Authors own calculation from WTO data.

Parenthesis shows negative value.

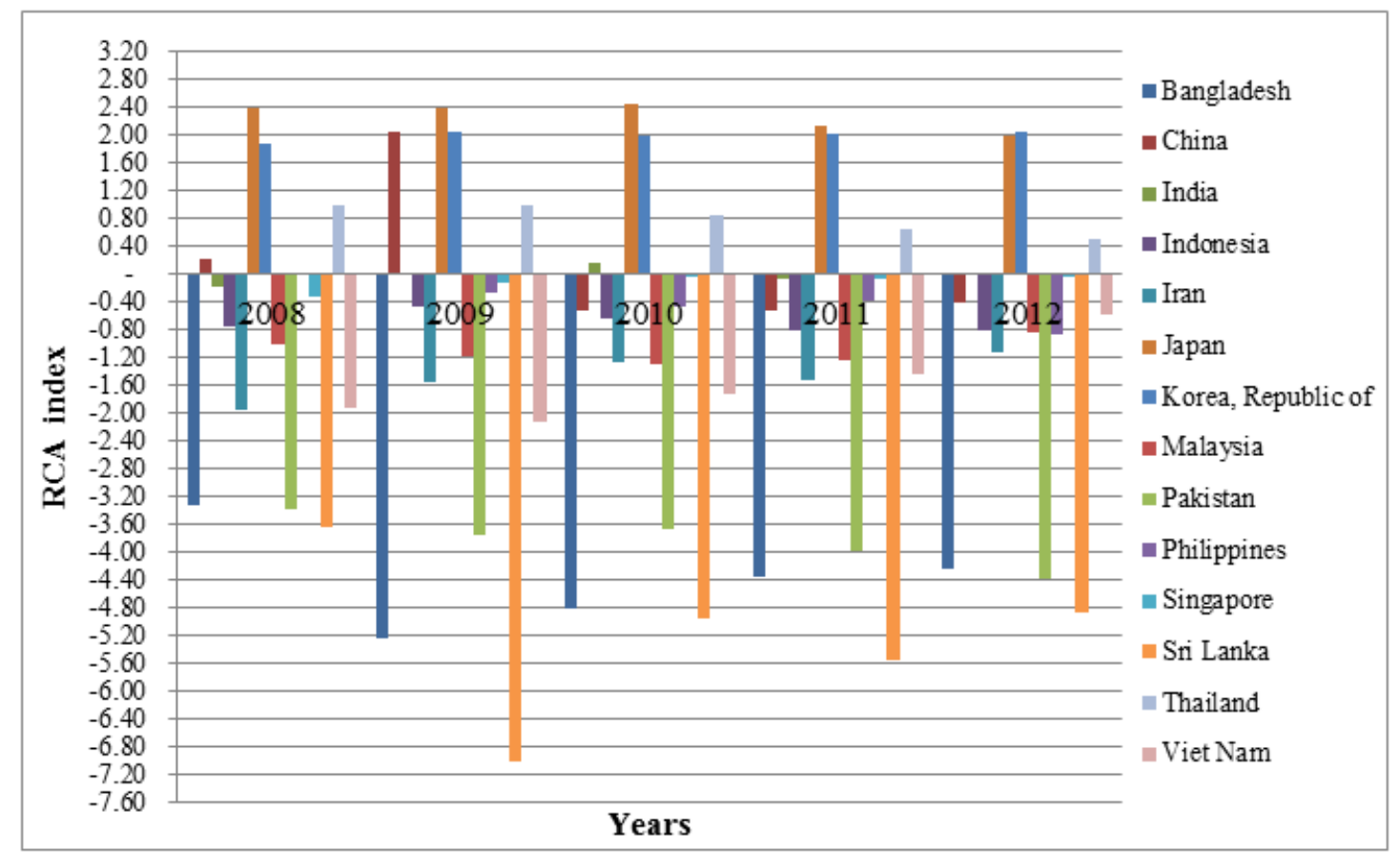

\section{References}

[1] Attanasio, O. P., Koujianou Goldberg, P., \&Kyriazidou, E. (2008). Credit Constraints in the Market for Consumer Durables: Evidence from Micro Data on Car Loans. International Economic Review, 49(2), 401-436.

[2] Balassa, B. (1965). Trade Liberalisation and "Revealed" Comparative Advantage. The Manchester School, 33(2), 99123.
[3] Baltagi, Badi. (2008). Econometric Analysis of Panel Data: Wiley. com.

[4] Bekmez, S., \&Komut, M. (2006). Competitiveness of Turkish Automotive Industry: A Comparison with European Union Countries. Human and Economic Resources Proceedings Book, 180.

[5] Breusch, T. S., \& Pagan, A. R. (1980). The Lagrange Multiplier test and its Applications to Model Specification in Econometrics. The Review of Economic Studies, 47(1), 239253. 
[6] Buckley, P. J., Clegg, J., Zheng, P., Siler, P. A., \&Giorgioni, G. (2007). The Impact of Foreign Direct Investment on the Productivity of China's Automotive Iindustry. Management International Review, 47(5), 707-724.

[7] Chen, B., Abeles, E., \& Burke, A. (2004.). Effect of Emissions Regulation on Vehicle Attributes, Cost, and Price.

[8] Czuchry, A., Yasin, M., \&Khuzhakhmetov, D. L. (2009). Enhancing Organizational Effectiveness through the Implementation of Supplier Parks: The Case of the Automotive Industry. Journal of International Business Research, 8(1), 45-61.

[9] Fagerberg, J., \&Verspagen, B. (2002). Technology-gaps, Innovation-diffusion and Transformation: An Evolutionary Interpretation. Research Policy, 31(8), 1291-1304.

[10] Fai, F. M., \& Morgan, E. J. (2007). Innovation, Competition and Regulatory Change: Assessing Interrelationships at the Industry Level. Management International Review, 47(5), 767-785.

[11] Gallagher, K. S. (2003). Foreign Technology in China's Automobile Industry: Implications for Energy, Economic Development, and Environment. China Environment Series, 1(6), 1-18.

[12] Hunya, G. (2000). International Competitiveness Impacts of FDI in CEECs (No. 268). The Vienna Institute for International Economic Studies.

[13] Jaffe, A. B., \& Palmer, K. (1997). Environmental Regulation and Innovation: A Panel Data Study. Review of Economics and Statistics, 79(4), 610-619.

[14] Judson, R. A., \& Owen, A. L. (1999). Estimating Dynamic Panel Data Models: A Guide for Macroeconomists. Economics letters, 65(1), 9-15.

[15] Kumar, R., \&Chadee, D. (2002). Competitiveness of Asian Firms: An Analytical Framework (No. 4). ERD Working Paper Series, (37).

[16] Le, Q. P. (2010). Evaluating Vietnam's Changing Comparative Advantage Patterns. ASEAN Economic Bulletin, 27(2), 221230 .
[17] Lee, J. W. (1993). International Trade, Distortions, and LongRun Economic Growth. Staff Papers-International Monetary Fund, 299-328.

[18] Martin, R. L. (2003). A Study on the Factors of Regional Competitiveness. Report for the European Commission Directorate-General Regional Policy. Cambridge University.

[19] Muhammad, F., Hussin, M. Y. M., \&AbRazak, A. (2010). Automobile Sales and Macroeconomic Variables: A Pooled Mean Group Analysis for Asean Countries Journal of Business and Management, 2(1), 15-21.

[20] Narayanan, B. G. (2010). Determinants of Competitiveness of the Indian Auto Industry. ICRIER Working Paper No. 201.

[21] Porter, M. E., \& Van der Linde, C. (1995). Green and Competitive: Ending the Stalemate. Harvard business review, 73(5), 120-134.

[22] Smith Jr, D. F., \& Florida, R. (1994). Agglomeration and Industrial Location: An Econometric Analysis of JapaneseAffiliated Manufacturing Establishments in AutomotiveRelated Industries. Journal of Urban Economics, 36(1), 23-41.

[23] Triebswetter, U., \&Wackerbauer, J. (2008). Integrated Environmental Product Innovation and Impacts on Company Competitiveness: A Case Study of the Automotive Industry In the Region of Munich. European Environment, 18(1), 30-44.

[24] Wad, P. and V. C. Govindaraju (2011). Automotive Industry in Malaysia: An Assessment of its Development. International Journal of Automotive Technology and Management, 11(2), $152-171$.

[25] Winston, C. (1987).Blind intersection: Policy and the Automobile Industry. Retrieved from http://www.osti.gov/scitech/servlets/purl/5617711

[26] Wooldridge, Jeffrey M. (2002). Econometric Analysis of Cross-section and Panel Data: The MIT Press. Cambridge, Massachusetts, London, England. 